\title{
The Effect of Presence Versus Absence of Reading Task and its Difficulty Level on Reading Strategies Use ${ }^{1}$
}

\author{
Elaheh Sotoudehnama and Fereshteh Azimfar \\ Alzahra University, Teheran \\ Iran
}

Received: 14 July 2010 / Accepted: 22 December 2010

ISSN: $1697-7467$

\begin{abstract}
This study is an attempt to investigate the effect of presence vs. absence of a reading task (easy vs. difficult) and language proficiency level on the L2 learners' use of strategies. The findings indicated that including a reading task has no impact on strategy assessment; there is no significant difference between EFL students' overall reported strategies in different task conditions, and also the high-proficient learners used more reading strategies than the low-proficient ones. Moreover, opposite to Oxford el al.'s (2004) finding, there was no significant difference in the learners' strategies use considering the interaction between task difficulty and language proficiency. Keywords: task difficulty level; presence versus absence of task; task and reading strategies; reading task and reading strategies.
\end{abstract}

El efecto de la presencia frente a la ausencia de la actividad y nivel de la lectura en el uso de la estrategia de lectura

RESUMEN: En este trabajo intentamnos investigar el efecto de la presencia o ausencia de una tarea de lectura (fácil frente a difícil) y el nivel de dominio de la lengua en el uso de estrategias en los aprendices L2. Los resultados mostraron que la inclusión de tareas de lectura no tiene un impacto sobre la evaluación de la estrategia, destacando que los alumnos de un nivel superior usaron más estrategias que aquéllos con un nivel inferior. Según los resultados y al contrario de los resultados obtenidos por Oxford y otros (2004) no existe ninguna relación directa entre el nivel de textos de lectura y el nivel de las destrezas adquiridas.

Palabras claves: dificultad de nivel de la tarea; presencia frente a ausencia de actividad; tareas y estrategias de lectura; estrategias y tarea de lectura.

\section{INTRODUCTION}

Within the field of education during the last two decades, a gradual but significant shift has taken place, resulting in less focus on teachers and teaching and greater

1 This article has been financially supported by Vice Chancellor for Research, Alzahara University 
emphasis on learners and learning (Nunan, 1988). One consequence of this shift was an increasing awareness and interest in resources for learning strategies in foreign and second language teaching and learning. Researchers such as Oxford (1990), Cohen (1987), and O'Malley and Chamot (1990) have stressed that effective learners use a variety of different strategies and techniques in order to solve problems they face while acquiring or producing the language. Research in language learning strategies demonstrates that the use of language learning strategies is somehow inevitable; what differs among the learners is the frequency and variety which depend on a number of variables (Chamot \& Kupper, 1989).

Assessing language learning strategy use through the questionnaire which usually asks students to report on their general use of language learning strategies has become commonplace around the world. Although general learning strategy questionnaires will remain important, task-based strategy assessment may have an increasing role in a way that examines specific strategy use when students do a particular L2 task (Oxford et al. 2004). As different language tasks require the use of different strategies, in the present study it is aimed to investigate whether there is any significant relationship between the presence of reading task and the use of reading strategies and also to examine whether students' reported reading strategies differ based on the difficulty level of the reading task. In other words attempt will be made to see if self- reported questionnaires can be considered as reliable instruments for checking strategies use. In addition, the relationship between the use of reading strategies and language proficiency is investigated, too.

\section{LITERATURE REVIEW}

The importance of language learning strategies has been proven and emphasized by many researchers as one of the key dimensions for successful language learning (Cohen, 1998; O’Malley \& Chamot 1990; Oxford, 1990; Wenden \& Rubin, 1987). The researches in reading comprehension have revealed the use of strategies by readers differently in the reading process (Block, 1986, 1992). According to Chamot (2004), strategic learners have the ability to use the appropriate learning strategies and also the ability to understand what a task involves.

Researches in different fields began to investigate various characteristics of learners, and learning strategies, as «specific attacks that we [learners] make on a given problem» (Brown, 2000:124) received much attention. The lack of general success among language learners might indicate that no teaching method is significantly superior to any other method (Richards 1990). This is why in recent times many researchers have turned their attention to learner strategies (Oxford, 1985; Richards, 1990).

Within ESL/ EFL education, a number of definitions of learning strategies have been used by figures in the field (Cohen 1998; Rubin 1975, 1987; Rigney 1978 cited in Oxford \& Crookall 1989; Chamot 1987; O’Malley and Chamot 1990; Oxford 2001). The definitions provided are defective in one way or another, because as put «...there is no complete agreement on exactly what strategies are; how many exists; how they should be defined, demarcated, and categorized; and whether it is possible to create a real, scientifically validated hierarchy of strategies»(Oxford, 1990:17). As our concern in this study is 
learning strategies specifically used in respect to reading comprehension task, the Selfreport Reading Strategy Questionnaire (Oxford, et al., 2004) is used as an instrument to collect and analyze part of the data.

As far as models of reading are concerned, the bottom-up reading model emphasizes a part-to-whole processing of a text. In terms of reading, bottom-up models claim that the reader perceives every letter, organizes the perceived letters into words, and then organizes the words into phrases, clauses, and sentences. This decoding of the text includes visual focus on the identification of letters, noticing combinations of letters, recognition of words and processing sentences by their syntactic structures and so on (Macaro, 2003).

At the sentence level, learners use top - down strategies such as skimming and background knowledge to process information (Barnett, 1988; Carrell, 1989). Unlike bottomup strategies where the reader works from smaller units upward, top-down strategies focus on the meaning-based clues (Landry, 2002).

Those who consider the two processes, top-down and bottom- up, important, believe in the combination of two in form of interactive approach (Stanovich, 1980 cited in Abraham, 2000). One important part of interactive process theory emphasizes «schemata,» the reader's pre-existing concepts about the world and about the text to be read. The schema theory of reading also fits within the cognitively based view of reading. Schema theory describes the process by which readers combine their own background knowledge with the information in a text to comprehend that text (Stott, 2001).

Another aspect of this study is the strategy use while doing a specific kind of task. Various definitions have been proposed by different scholars in defining «task». As defined by Richards and Rogers (2001:224), a «task» as a central unit for curriculum and teaching is an «activity...such as finding a solution to a puzzle, reading a map, and giving directions, making a telephone call, writing a letter, or reading a set of instructions and assembling a toy». Similarly, Willis (1998:1) defines task as "a goal-oriented activity with a clear purpose such as "comparing two pictures and / or texts to find the differences; and solving a problem or designing a brochure". Ellis (2003: 16) defines task as «a workplan that requires learners to process language pragmatically in order to achieve an outcome that can be evaluated in terms of whether the correct or appropriate propositional content has been conveyed.» and Nunan (2004) defines it as:

a piece of classroom work that involves learners in comprehending, manipulating, producing or interacting in the target language while their attention is focused on mobilizing their grammatical knowledge in order to express meaning, and in which the intention is to convey meaning rather than to manipulate form. The task should also have a sense of completeness, being able to stand alone as a communicative act in its own right. (p. 4)

When students are asked to complete a questionnaire of L2 learning strategies, many students think about L2 task they have done in the past. Some think about specific tasks, while others consider their experience of L2 tasks in a more general way. Therefore, even when students answer the same strategy questionnaire, they may have different interpretations of their own L2 task experience. These different interpretations may influence the reporting of the strategy use in terms of the comparability of responses to the same items across students. Also, if a task is not present as part of L2 strategy assessment, 
then it is unclear whether students are considering their typical strategy use in reference to difficult or to easy tasks.

According to Cohen (1998), strategies can be used effectively by various learners who do particular types of L2 learning task at different proficiency levels. Green and Oxford (1995) believe that the SILL (Strategy Inventory for Language Learning) and other similar strategy assessment surveys provide a general picture of strategy use and not a specific one. This research has attempted to confirm how strategies are used as learners engage in actual tasks.

\section{Significance OF THE STUdy}

Usually researches on language learning strategies (Ehrman and Oxford, 1989; Oxford and Nyikos, 1989; Ehrman and Oxford, 1990; and Green and Oxford, 1995) have used the self-report Strategy Inventory for Language Learning (SILL) as a kind of questionnaire that asks about the general strategies used by L2 learners without having them do any L2 task. However according to Oxford et al. (2004) when a specific task is included in second language strategy assessment, the respondents focus on the strategies they use while doing the particular task and therefore, the task influences their reporting of strategies. Moreover, as it is mentioned by Oxford et al. (2004), task difficulty has an important influence on the types and frequencies of strategy use and leads to different strategy reports.

Another important factor in assessing the strategy use is the role of language proficiency. Researchers usually report a relationship between the language proficiency level and the strategies use (Green and Oxford 1995, Oxford and Ehrman 1995). But in their studies Oxford et al. (2004) did not find the relationship related to the language proficiency level but due to the interaction of language proficiency level and task condition (No task, Easy task, and Difficult task). It is worth mentioning that they checked the language proficiency level through the same instrument which was used as task condition including two reading passages followed by some multiple choice questions. In this study two different kinds of materials were used to check task difficulty and language proficiency levels. In investigations conducted on strategy use in Iran (Khajeh, 2002; Hosseini, 2003; Lotfiyan Moghadam 2003; and Yadegari, 2004), task presence and task difficulty were not investigated. Hence, the present study specifically attempts to investigate if there is any relationship between presence/absence of a task, difficulty level of the reading tasks and strategy use among Iranian EFL learners and to check if students with different language proficiency levels use different language learning strategies. In other words this study is the replication of Oxford et al's study (2004) but in the EFL context of Iran and with a different instrument (TOEFL) for measuring the language proficiency level.

\section{RESEARCH QUESTIONS}

1. Are there any main effects or interaction effect on reading strategy use considering the two independent variables of reading task condition (No Task, Easy Task, and Difficult Task) and English language proficiency (high and low)? 
2. Is there any significant difference between the high and low proficient learners in the use of each strategy within each of the task conditions (i.e. No Task, Easy Task, Difficult Task)?

\section{DEFINITION OF KEY TERMS}

Reading Strategies: They are defined as «ways of accessing text meaning which are employed flexibly and selectively» by the reader «to draw effectively on existing linguistic and background knowledge.» (Carter \& Nunan, 2001: 225) In this study reading strategies are indicated through the scores obtained by the participants in answering the 35 -item strategies questionnaires designed by Oxford et al. (2004).

Task: As defined by Crookes (1986:1) a task is «a piece of work or an activity, usually with a specified objective, undertaken as part of an educational course, at work, or used to elicit data for research» (cited in Richards \& Rodgers 2001: 233). This definition includes not only summaries, essays, and class notes, but in some language classrooms, drills, dialogue readings, and any other tasks that teachers use to obtain their objectives (Richards \& Rodgers, 2001). The task type in this study is reading passages for both overall comprehension and specific details and answering a series of related questions.

Task Difficulty: Difficulty of task refers to the complicated cognitive processing operations that are loaded on learners (Oxford et al., 2004). As readability describes the ease with which a reading passage can be read, in this study the difficulty of the reading task is determined in terms of 'readability' of a reading passage based on Flesch Reading Ease Scale. The reading passage is difficult if the readability index of the reading passage is one standard deviation below the average readability index of the four reading texts selected from the students' textbook and it is easy if the readability index of the reading passage is one standard deviation above the average readability index of the four reading texts selected from the learners' textbook.

Language Proficiency: In this study proficiency in language refers to the scores learners obtain in the TOEFL test (2004). The learners with TOEFL scores within 0.5 and 2 standard deviations above or below the mean will be considered as high and lowproficiency group respectively.

\section{6. Мethod}

\subsection{Participants}

The participants were 37 students who were all foreign language learners of two language institutions in Iran; ZabanSara and Apadana Language Institute. These institutes use the same material and the same system of language teaching. The participants consisted of 20 male and 17 female students with ages ranging from 19 to 35. Based on the above mentioned criterion, the study included high-proficient group $(\mathrm{N}=19)$ and lowproficient group $(\mathrm{N}=18)$. 


\subsection{Materials and Instrumentations}

The materials and instruments in this study include TOEFL, Reading Tasks, Reading Strategy Questionnaire of Oxford et al. (2004), and Hosenfeld et al.'s (1981) think-aloud Strategy Protocol (cited in Oxford, 1990).

\subsubsection{Test of English as Foreign Language (TOEFL)}

As explained earlier, for assigning learners as high or low-proficient for this study, a sample of TOEFL test i.e. complete paper test from Longman Complete Course for TOEFL Test published by Pearson education (2004) was used.

\subsubsection{Task}

The task required the participants to read two written reading passages and answer the 5 related multiple-choice questions which followed each reading text. The two passages discussed different aspects of the same subject matter of «learning styles and strategies.» To control for topic familiarity and background knowledge, it was checked with the participants' teachers to determine whether the students had discussed, heard about, or read about this topic before, and it was assured that they had not. The content of both reading passages came from the research reported in (Oxford et. al 2004). The first reading passage was to be easy (for the Easy Task condition) and the second one difficult (for the Difficult Task condition).

The reading text was judged to be easy or difficult based on the average readability of at least four reading passages taken from the learners' textbook, using Flesch's Reading Ease Scale. In other words, four samples of reading texts were selected randomly from the participants' textbook (FCE; First Certificate Gold Course book) which were used in both institutes. Second, Flesch's readability formula was applied and the average readability was determined. The Flesch average readability index for the four reading texts of the participants' textbook was 74.5 and the Flesch indices for the reading passages in our study were 83.43 for the easy passage and 52.15 for the difficult passage. These indices indicate that the readability of the difficult and easy reading passage is at least one standard deviation below and above the average readability index for the four reading texts respectively based on the learners' textbooks. In other words, the readability index of the two passages selected for the difficult and easy tasks were within the range of $74.5 \pm 11.38$ from the mean, i.e. 63.12 to 85.88 .

\subsubsection{Reading Strategy Questionnaire (RSQ)}

This study used a self-report Reading Strategy Questionnaire taken from Oxford et al. (2004) including 35 questions. Responses were based on a 5-point Likert scale from 0 (almost never) to 5 (almost always) showing the degree of strategy use.

\subsubsection{Reading Think-Aloud Protocol}

In order to discover more about the strategies that individual learners use while accomplishing specific language tasks and in order to get a more comprehensive picture, 
a think-aloud strategy interview was carried out in the learners' native language, i.e., Persian (Farsi). In this regard, four participants were interviewed in two task conditions (Easy Reading Task, Difficult Reading Task). They were chosen by selecting the two highest and the two lowest scores from each proficiency level. During reading thinkaloud interview, the four selected participants were required to read the easy and difficult texts and stop at those parts as the interviewer noted and think aloud (details in part 7.2). In order to express their thoughts without any limitations, they were also permitted to use their native language, Persian.

\subsection{Procedure}

To make sure that participants in each group were homogenous first a TOEFL test (2004) was administered to divide them into low and high-proficient learners. Next, the participants were asked to answer the questionnaire in three stages, which were no task condition, easy task condition, and difficult task condition.

No Task Condition (NTC):

In the first stage, the participants were asked to complete the RSQ without doing any reading task.

Easy Task Condition (ETC):

In the second stage, which was two weeks after the first stage, the participants were first required to read the easy reading passage and answer five related reading comprehension questions within a limited time (20 minutes), then they were asked to fill out the same RSQ they completed in the first stage.

Difficult Task Condition (DTC):

In the third stage, which was two weeks after the second stage, the participants first read the difficult reading passage and answered the five related reading comprehension questions within a limited time (20 minutes) and then they were asked to fill out the same RSQ.

\subsection{Data Analysis}

In order to answer the first question, i.e., to find the main effect for task conditions, the main effect of proficiency level, and the interaction of these two independent variables, a Repeated- Measure Analysis of Variance (ANOVA) using a Mixed Plot (Factorial Design) with the alpha set at 0.05 was conducted.

To answer the 2nd question, i.e., in order to identify whether the high and lowproficient learners report different use of each strategy item within each of the three task conditions, a multiple analysis of variance, i.e., MANOVA, was conducted. 


\section{RESUlts}

The results are related to the findings for reading strategy questionnaire considering the three task conditions with different levels of language proficiency and think aloud protocol.

\subsection{Results of analysis of Reading Strategy Questionnaire (RSQ) in the three task conditions}

This questionnaire consisted of 35 reading strategy questions investigating the strategies used by participants when they are not doing any reading task, and when they are doing easy and difficult tasks. It consists of three parts. The questions include strategies that are used before reading, while reading, and after reading. The RSQ was given to participants to be answered in three stages of No Task, Easy Task, and Difficult Task condition. Furthermore, in order to prevent misunderstanding, the translation of the RSQ in their native language was also accompanied which was approved by two PhD TEFL professors whose native language was Persian. Although the participants were provided with the translation, it was observed that few participants used the translation of the questionnaire.

To answer the first research question, a One-way ANOVA with Repeated Measures was conducted. Task condition (No Task, Easy Task, and Difficult Task) was considered as within-subjects and language proficiency as between- subjects factor. Table 1 provides the descriptive statistics.

Table1. Descriptive Statistics of high and low proficient learners in three task conditions

\begin{tabular}{|cr|c|c|c|}
\hline Task & $\begin{array}{r}\text { Language } \\
\text { proficiency }\end{array}$ & $\mathrm{N}$ & Mean & Std. Deviation \\
\hline No Task & High & 19 & 104.26 & 10.359 \\
& Low & 18 & 92.67 & 12.696 \\
& Total & 37 & 98.62 & 12.818 \\
\hline Easy Task & High & 19 & 101.42 & 9.530 \\
& Low & 18 & 92.22 & 13.765 \\
& Total & 37 & 96.95 & 12.514 \\
\hline Difficult Task & High & 19 & 109.11 & 15.684 \\
& Low & 18 & 94.50 & 10.473 \\
& Total & 37 & 102.00 & 15.151 \\
\hline
\end{tabular}

As it is shown, the mean of strategy use in DT is more than two other task conditions and the mean in NT is more than ET for high proficient learners. The case is exactly the same for the low proficient ones.

To find out if this difference is meaningful, the Repeated Measures ANOVA was conducted. Table 2 provides the sphericity. 
Table 2. Mauchly's Test of Sphericity

\begin{tabular}{|c|c|c|c|c|c|c|c|}
\hline \multirow[b]{2}{*}{$\begin{array}{l}\text { Within Subjects } \\
\text { Effect }\end{array}$} & \multirow{2}{*}{$\begin{array}{c}\text { Mauchly's } \\
\text { W }\end{array}$} & \multirow{2}{*}{$\begin{array}{l}\text { Approx. } \\
\text { Chi-Square }\end{array}$} & \multirow[b]{2}{*}{$\mathrm{df}$} & \multirow[b]{2}{*}{ Sig. } & \multicolumn{3}{|c|}{ Epsilon $^{\mathrm{a}}$} \\
\hline & & & & & $\begin{array}{l}\text { Greenhouse- } \\
\text { Geisser }\end{array}$ & Huynh-Feldt & $\begin{array}{l}\text { Lower- } \\
\text { bound }\end{array}$ \\
\hline Task Condition & .960 & 1.429 & 2 & .489 & .962 & 1.000 & .500 \\
\hline
\end{tabular}

Based on table 2, the sphericity assumption was not violated (Mauchly's W= .960, $\mathrm{df}=2$; p .05). Table 3 demonstrates the effect of language proficiency on strategy use.

Table 3.Tests of Between- Subjects Effects

\begin{tabular}{|c|c|c|c|c|c|}
\hline Source & $\begin{array}{c}\text { Type III Sum of } \\
\text { Squares }\end{array}$ & df & Mean Square & F & Sig. \\
\hline Intercept & 1087769.287 & 1 & 1087769.287 & 3704.764 & .000 \\
\hline proficiency & 3861.215 & 1 & 3861.215 & 13.151 & .001 \\
\hline Error & 10276.479 & 35 & 293.614 & & \\
\hline
\end{tabular}

As table in 3 indicates, there is a significant difference $\left(\mathrm{F}_{(1,35)}=13.151, \mathrm{p}<.05\right)$ in the strategy use between high and low proficient L2 learners.

\section{Table 4. Tests of Within-Subjects Contrasts}

\begin{tabular}{|c|c|c|c|c|c|}
\hline Source & $\begin{array}{c}\text { Type III } \\
\text { Sum } \\
\text { of Square }\end{array}$ & df & Mean Square & F & Sig \\
\hline TASK & 476.348 & 2 & 238.174 & 3.008 & .056 \\
\hline Task *proficiency & 135.663 & 2 & 3.000 & .857 & .429 \\
\hline Error & .106 & 70 & 79.189 & & \\
\hline
\end{tabular}

Based on the results in table 4 , neither task conditions $\left(\mathrm{F}_{(2,70)}=3.008, \mathrm{p}>0.05\right)$, nor the interaction of task conditions and language proficiency $\left(\mathrm{F}_{(2,70)}=.857, \mathrm{p}>0.05\right)$ showed any significant difference in the participants' use of reading strategies.

Table 5, 6, and 7 show the results of the significant difference between the high and low proficient language learners in the use of each strategy in each of the No Task, Easy task, and Difficult Task Condition respectively. 
Table 5. Strategies showing significant differences by proficiency level within No Task Condition

\begin{tabular}{|cc|c|c|c|c|c|}
\hline \multicolumn{2}{|c|}{ Strategy } & $\begin{array}{c}\text { High-Proficiency } \\
\text { (HP) Mean }\end{array}$ & $\begin{array}{c}\text { Low- } \\
\text { Proficiency } \\
\text { (LP) Mean }\end{array}$ & F & Significance & df \\
\hline Item 6 & $($ LP) & 2.00 & 2.50 & 5.578 & .024 & 1 \\
\hline Item 8 & $(\mathrm{HP})$ & 2.84 & 2.44 & 4.663 & .038 & 1 \\
\hline Item 20 & $(\mathrm{HP})$ & 2.53 & 1.50 & 17.714 & .000 & 1 \\
\hline Item 21 & $(\mathrm{HP})$ & 2.16 & 1.11 & 19.367 & .000 & 1 \\
\hline Item 24 & $(\mathrm{LP})$ & 2.37 & 2.89 & 7.184 & .011 & 1 \\
\hline Item 27 & $(\mathrm{HP})$ & 1.68 & 1.22 & 6.156 & .018 & 1 \\
\hline Item 29 & $(\mathrm{HP})$ & 2.32 & 1.33 & 25.796 & .000 & 1 \\
\hline Item 30 & $(\mathrm{HP})$ & 2.21 & 1.61 & 7.530 & .010 & 1 \\
\hline Item 32 & $(\mathrm{HP})$ & 2.05 & 1.44 & 4.713 & .037 & 1 \\
\hline Item 33 & $(\mathrm{HP})$ & 2.58 & 2.00 & 6.520 & .015 & 1 \\
\hline
\end{tabular}

$0.00-1.50=$ Rather low use, usually not used

$1.60-2.50=$ Moderate use, used sometimes but not usually

$2.60-3.00=$ very high use, always used

As table 5 presents, in the No Task condition, the High-Proficient (HP) group reported employing eight strategy items significantly more than the Low-Proficient (LP) group: strategies $8,20,21,2729,30,32$, and 33, while two strategy items (6, and 24) were reported as used significantly more by low-proficient learners than high-proficient ones.

Table 6. Strategies showing significant differences by proficiency level within Easy Task condition

\begin{tabular}{|c|c|c|c|c|c|}
\hline Strategy & $\begin{array}{c}\text { High- } \\
\text { Proficiency } \\
(\mathrm{HP})\end{array}$ & $\begin{array}{c}\text { Low-Proficiency } \\
(\text { LP) }\end{array}$ & $\mathrm{F}$ & Significance & df \\
\hline Item 1 (HP) & 2.84 & 2.44 & 7.339 & .010 & 1 \\
\hline Item 7 (HP) & 2.42 & 1.89 & 6.358 & .016 & 1 \\
\hline Item 8 (HP) & 2.84 & 2.28 & 8.488 & .006 & 1 \\
\hline Item 14 (HP) & 2.26 & 2.00 & 4.926 & .033 & 1 \\
\hline Item 17 (HP) & 2.68 & 2.28 & 4.561 & .040 & 1 \\
\hline Item 18 (LP) & 2.05 & 2.56 & 5.316 & .027 & 1 \\
\hline Item 20 (HP) & 2.21 & 1.50 & 7.541 & .009 & 1 \\
\hline Item 21 (HP) & 1.89 & 1.17 & 10.528 & .003 & 1 \\
\hline Item 24 (LP) & 2.32 & 3.00 & 18.686 & .000 & 1 \\
\hline Item 25 (HP) & 3.00 & 2.28 & 46.730 & .000 & 1 \\
\hline Item 27 (HP) & 1.63 & 1.17 & 6.403 & .016 & 1 \\
\hline Item 29 (HP) & 2.47 & 1.78 & 11.314 & .002 & 1 \\
\hline
\end{tabular}

$0.00-1.50=$ Rather low use, usually not used

$1.60-2.50=$ Moderate use, used sometimes but not usually

$2.60-3.00=$ very high use, always used 
As table 6 indicates, the Easy Task condition had twelve significant differences between proficiency levels. Ten of these differences were used more by High-Proficient learners (strategies 1, 7, 8, 14, 17, 20, 21, 25, 27, 29), unlike two strategies (strategies 18, and 24) which were used more by the low proficient learners.

Table 7. Strategies showing significant differences by proficiency level within Difficult Task condition

\begin{tabular}{|c|c|c|c|c|c|}
\hline Strategy & $\begin{array}{c}\text { High- } \\
\text { Proficiency } \\
\text { (HP) Mean }\end{array}$ & $\begin{array}{l}\text { Low-Proficiency } \\
\text { (LP) Mean }\end{array}$ & $\mathrm{F}$ & Significance & $\mathrm{df}$ \\
\hline Item $3 \quad(\mathrm{HP})$ & 2.47 & 1.89 & 4.914 & .033 & 1 \\
\hline Item $6 \quad$ (LP) & 2.00 & 2.67 & 6.536 & .015 & 1 \\
\hline Item $7 \quad(\mathrm{HP})$ & 2.32 & 1.78 & 6.154 & .018 & 1 \\
\hline Item $8 \quad(\mathrm{HP})$ & 2.63 & 2.00 & 8.949 & .005 & 1 \\
\hline Item 9 (LP) & 2.16 & 2.78 & 12.899 & .001 & 1 \\
\hline Item 14 (HP) & 2.47 & 2.00 & 10.689 & .002 & 1 \\
\hline Item $16 \quad(\mathrm{HP})$ & 2.42 & 1.89 & 6.358 & .016 & 1 \\
\hline Item 17 (HP) & 2.63 & 2.22 & 4.701 & .037 & 1 \\
\hline Item 20 (HP) & 2.58 & 1.61 & 17.921 & .000 & 1 \\
\hline Item 21 (HP) & 2.00 & 1.22 & 11.437 & .002 & 1 \\
\hline Item 24 (LP) & 2.21 & 2.89 & 11.509 & .002 & 1 \\
\hline Item 27 (LP) & 2.05 & $1 / 39$ & 9.361 & .004 & 1 \\
\hline Item 29 (HP) & 2.37 & 1.67 & 12.826 & .001 & 1 \\
\hline
\end{tabular}

$0.00-1.50=$ Rather low use, usually not used

$1.60-2.50=$ Moderate use, used sometimes but not usually

$2.60-3.00=$ very high use, always used

As table 7 shows, the Difficult Task condition had the greatest number of significant differences in strategy use by proficiency level. In this condition, the High-Proficient group used nine strategies $(3,7,8,14,16,17,20,21$, and 29) significantly more often, while the Low Proficient group applied four strategies $(6,9,24$, and 27) significantly more than the High-Proficient group. Table 8 demonstrates nineteen strategies which were significantly different between high and low-proficient learners within each of the task conditions in one glance. 
Table 8. Significantly used strategies by high and low proficient learners in the three task conditions in comparison

\begin{tabular}{|c|c|c|c|c|c|c|}
\hline Reading Strategies & \multicolumn{2}{|c|}{$\begin{array}{l}\text { No Task } \\
\text { Context }\end{array}$} & \multicolumn{2}{|c|}{$\begin{array}{l}\text { Easy Task } \\
\text { Context }\end{array}$} & \multicolumn{2}{|c|}{$\begin{array}{l}\text { Difficult Task } \\
\text { context }\end{array}$} \\
\hline $\begin{array}{l}\text { Item1: Using the title to predict the } \\
\text { contents. }\end{array}$ & & & $x$ & & & \\
\hline $\begin{array}{l}\text { Item3: Skimming the text first and } \\
\text { later reading for details }\end{array}$ & & & & & $x$ & \\
\hline $\begin{array}{l}\text { Item6: Focusing on the tenses of the } \\
\text { verb }\end{array}$ & & $x$ & & & & $x$ \\
\hline $\begin{array}{l}\text { Item7: Trying to understand the } \\
\text { meaning of every word into the } \\
\text { native language }\end{array}$ & & & $x$ & & $x$ & \\
\hline $\begin{array}{l}\text { Item8: Translating each sentence } \\
\text { into the native language }\end{array}$ & $x$ & & $x$ & & $x$ & \\
\hline $\begin{array}{l}\text { Item9: Starting reading from the } \\
\text { first paragraph all the way through } \\
\text { to the last paragraph }\end{array}$ & & & & & & $x$ \\
\hline Item14: Skipping unknown words & & & $x$ & & $x$ & \\
\hline $\begin{array}{l}\text { Item 16: Understanding the meaning } \\
\text { of an unknown word by dividing } \\
\text { into parts }\end{array}$ & & & & & $x$ & \\
\hline $\begin{array}{l}\text { Item17: Guessing the meaning of a } \\
\text { word or phrase using clues from the } \\
\text { text. }\end{array}$ & & & $x$ & & $x$ & \\
\hline $\begin{array}{l}\text { Item18: Guessing the meaning using } \\
\text { information about the topic }\end{array}$ & & & & $x$ & & \\
\hline Item20: Underlining important parts & $x$ & & $x$ & & $x$ & \\
\hline $\begin{array}{l}\text { Item21: Marking important parts, } \\
\text { using colored pens or drawing stars }\end{array}$ & $x$ & & $x$ & & $x$ & \\
\hline $\begin{array}{l}\text { Item24: Making a picture in mind } \\
\text { about what the text is saying }\end{array}$ & & $x$ & & $x$ & & $x$ \\
\hline $\begin{array}{l}\text { Item25: Understanding the meaning } \\
\text { without translating the text into } \\
\text { native language }\end{array}$ & & & $x$ & & & \\
\hline $\begin{array}{l}\text { Item27: Following the lines with } \\
\text { finger or pen }\end{array}$ & $x$ & & $x$ & & $x$ & \\
\hline $\begin{array}{l}\text { Item29: Skipping the sentences not } \\
\text { understood }\end{array}$ & $x$ & & $x$ & & $x$ & \\
\hline $\begin{array}{l}\text { Item 30: Predicting what will come } \\
\text { next }\end{array}$ & $x$ & & & & & \\
\hline Item32: Writing key words & $x$ & & & & & \\
\hline $\begin{array}{l}\text { Item 33: Figuring out the main idea } \\
\text { of each paragraph }\end{array}$ & $x$ & & & & & \\
\hline
\end{tabular}




\subsection{Think-Aloud Protocol}

During reading think-aloud interview, the four selected participants, those who obtained the two highest and the two lowest scores from each proficiency level were required to read the easy and difficult texts and think aloud. It is worth remembering that interviewing each of the four selected participants and simultaneously recording their general behavior while they said out loud what they were doing, required a lot of time and since the participants of this study were not able to allocate such plenty of time, it was required to stop them paragraph by paragraph while reading, however, based on the experiences of the researcher and her familiarity with the language learning system in which the participants had been studying, she recognized some key words in the paragraphs that she thought they might be difficult for the learners and might cause them to use some strategies according to their language proficiency, therefore she found it better sometimes to stop them in the middle of the paragraphs. Most probably, more various strategies might have been exhibited, if students had been stopped sentence by sentence which was impossible due to time limitations in this study. In order to express their thoughts without any limitations, the participants were also permitted to use their native language, Persian. The stages of reading think-aloud procedures of the selected participants were all transcribed.

The following tables show the results of think aloud protocol and the strategies used by top and weak interviewees in easy and difficult task conditions respectively.

Table 12. The reading strategies used by top and weak learners in easy task condition

\begin{tabular}{|l|c|c|c|c|}
\hline \multicolumn{1}{|c|}{ STRATEGIES } & Top & Weak & $\begin{array}{c}\text { Top }> \\
\text { weak }\end{array}$ & $\begin{array}{c}\text { Top }< \\
\text { weak }\end{array}$ \\
\hline $\begin{array}{l}\text { Skipping unknown and } \\
\text { unnecessary words and trying to } \\
\text { guess meaning from the context }\end{array}$ & $\times$ & $\times$ & & \\
\hline Translating & $\times$ & $\times$ & & \\
\hline $\begin{array}{l}\text { Reading Title \& making } \\
\text { inferences }\end{array}$ & & & $\times$ & \\
\hline $\begin{array}{l}\text { Linking the context with what } \\
\text { they already know }\end{array}$ & & & $\times$ & \\
\hline Using knowledge of the world & & & & $\times$ \\
\hline
\end{tabular}


Table 13. The reading strategies used by top and weak learners in difficult task condition

\begin{tabular}{|l|c|c|c|c|}
\hline \multicolumn{1}{|c|}{ STRATEGIES } & Top & Weak & $\begin{array}{c}\text { Top }> \\
\text { weak }\end{array}$ & $\begin{array}{c}\text { Top }< \\
\text { weak }\end{array}$ \\
\hline \multicolumn{1}{|c|}{ Translating } & $\times$ & $\times$ & & \\
\hline $\begin{array}{l}\text { Using context in preceding and } \\
\text { succeeding sentences and } \\
\text { paragraphs }\end{array}$ & $\times$ & $\times$ & & \\
\hline $\begin{array}{l}\text { Identifying grammatical } \\
\text { category of words }\end{array}$ & $\times$ & $\times$ & & \\
\hline $\begin{array}{l}\text { Reading and predicting based } \\
\text { on the title }\end{array}$ & & & $\times$ & \\
\hline $\begin{array}{l}\text { trying to figure out the main } \\
\text { idea of each paragraph }\end{array}$ & & & $\times$ & $\times$ \\
\hline $\begin{array}{l}\text { Skipping unknown and } \\
\text { unnecessary words and } \\
\text { continuing even if } \\
\text { unsuccessful }\end{array}$ & & & & $\times$ \\
\hline Reading difficult parts aloud & & & & $\times$ \\
\hline $\begin{array}{l}\text { Asking the meaning of } \\
\text { unknown words }\end{array}$ & & & & \\
\hline
\end{tabular}

\section{Results AND CONClusions}

As far as the main effects of task conditions on strategy use is concerned, the mean scores of Reading Strategy Questionnaire (RSQ) in the two proficiency groups showed rather similar direction across the three task conditions. The learners' strategy use appeared to decline in Easy Task condition and to increase in Difficult Task conditions in comparison to their self-report strategy use in No Task condition. It can be deduced that the easy reading passage did not seem to influence the learners' strategy use greatly, however when the difficult reading passage was presented, they had greater difficulty in comprehending the difficult text, thus leading them to use more strategies and with higher frequency. In other words, on one hand it can be inferred that when they were answering the questionnaire without doing any task, they were thinking about a rather difficult task, but when it came to the real task which was easy, the mean of the strategies use declined. On the other hand, when they were doing a real difficult task, the mean of strategy use was even more than what they had anticipated about themselves. However, as the statistical results show, the total or overall mean of strategy use did not differ significantly across the three task conditions; that is the presence and difficulty of reading task did not have any effect on the reading strategy use of the participants.

Considering the main effect of proficiency level on strategy use, the overall mean of strategy use differed significantly across the two proficiency levels (high vs. low) in 
a way that the high-proficient learners' strategy use appeared to be more than the lowproficient ones. In other words, the number of strategies or the mean of strategy use by the high-proficient groups was more in each of the three task conditions. This finding supports the results of research studies by O'Malley and Chamot (1990) and Oxford and Ehrman (1995), which showed that greater strategy use is often related to higher levels of language proficiency and is not in line with Oxford et al.'s study (2004) where language proficiency did not show main effect on reading strategy use. The reason might be due to this fact that in this study two different kinds of materials were used: one for measuring the task difficulty level and a standard TOEFL test for language proficiency level. While Oxford et al. (2004) had used one reading material measuring both sources. In fact they themselves have the suggestion for making this separation:

It would be good to have an external, standard measure of proficiency with which to identify levels prior to the study. In the case of current investigation, we created our own proficiency assessment because the institutions involved did not use a common proficiency metric.(P.36)

Unlike Oxford et al. (2004) who found significant effect on reading strategy use by the interaction of the task condition and language proficiency, in this study the result was only due to the language proficiency level and neither to task condition nor to their interaction. It may be concluded that doing a task is not a necessity for being able to report the strategies one uses because when one reports about one's strategies, in fact she has a concept of her strategies based on previous experiences which are somehow moderate, i.e., not too easy and not too difficult. In this study the judgment /self-report in no task condition was higher than the easy one and less than the difficult one. Moreover, it is the language proficiency which plays a more important role rather than the task.

Another suggestion provided by Oxford et al. (2004) is related to think aloud protocol.

Task based questionnaires are written, while think-aloud protocols are oral....To our knowledge, few if any systematic comparisons between task- based strategy questionnaires and think-aloud protocols have been made.(p.36)

As the reading think-aloud interviews' results at both easy and difficult stages of reading show, the main strategies that were used by all the selected participants either in easy or difficult task were translating into the native language and skipping in order to guess contextually. Based on these results, it is concluded that there is a match between the types of the strategies that were used in reading think-aloud interview at the two stages of Easy and Difficult Task and the types of strategies in the Reading Strategy Questionnaire. In other words, there was no other strategies used which was not included in the Reading Strategy Questionnaire, hence the use of this self-reported questionnaire can be considered a reliable tool for measuring the used strategies though some believe that self-report and think aloud techniques provide partly similar and partly different results (Levine \& Reves 1998) and some believe that the use of multiple measures can provide a more reliable result (Cromely \& Azevedo 2006). 


\section{REFERENCES}

Abraham, P. (2000) "Skilled reading: Top-down, bottom-up", available from: http://www.sabes.org/ resources/publications/fieldnotes/vol10/f02abrah.htm, accessed 16 may 2010.

Barnett, M. A. (1988). "Teaching reading in a foreign language". ERIC Digest, ED305829.

Block, E. (1986). "The comprehension strategies of second language readers", in TESOL Quarterly, 20.

Block, E. (1992). "See how they read: Comprehension monitoring of L1 and L2 readers", in TESOL Quarterly, 26,319-342.

Brown, D. H. (2000). Principles of Language Learning and Teaching. ( $4^{\text {th }}$ ed.). Addison Wesley Longman.

Carrell, P.L. (1989). "Metacognitive awareness and second language reading", in The Modern Language Journal, 73 , 2. 121-134.

Carter, R. \& Nunan, D. (2001). The Cambridge Guide to Teaching English to Speakers of Other Languages. Cambridge University Press.

Chamot, A. U. (1987) "The Learning strategies of ESL students", in A. Wenden \& J. Rubin (eds.), Learner Strategies in Language Learning. Prentice Hall, Englewood Cliffs NJ., 71-84.

Chamot, A. U. (2004). "Issues in language learning strategy research and teaching". Electronic Journal of Foreign Language Teaching 2004, 1,.1:14-26, available from: http://e-flt.nus.edu.sg/ v1n12004/chamot.htm, accessed 16 May, 2010.

Chamot, A. U. and Kupper, L. (1989) "Learning strategies in foreign language instruction", in Foreign Language Annals, 22, 13-24.

Cohen, A.D. (1987). "Studying learner strategies: How we get the Information", in A Wenden \& J. Rubin (eds.), Learner Strategies in Language Learning. Englewood Cliffs, NJ: PrenticeHall, 31-40.

Cohen, A. D. (1998). Strategies in Learning and Using a Second Language. Addison Wesley Longman.

Cromley, J.G. and Azevedo, R. (2006). "Self-report of reading comprehension strategies: What Are We Measuring? ", in Metacognition and Learning, 1, 3. pdf version.

Ehrman, M. \& Oxford, R. L. (1989). "Effects of sex differences, career choice and psychological type on adult language learning strategies", in The Modern Language Journal, 73, 1, 1-13.

Ehrman, M. \& Oxford, R. L. (1990). " Adults language learning styles and strategies in an intensive training setting", in The Modern Language journal, 74, No. 3, 311- 327.

Green, J. \& Oxford, R. L. (1995). "A closer look at learning strategies, L2 proficiency and gender", in TESOL Quarterly, 29,2, 261-297.

Hosseini, K. (2003). The relationship between Iranian EFL students' multiple intelligences and their use of language learning strategies. Unpublished master thesis, University of Tarbiat Moddares - Iran.

Khajeh, A. (2002). The relationship betweentTolerance of ambiguity, gender,level of proficiency and use of second language learning strategies. Unpublished master thesis, University of Tarbiat Moddares - Iran.

Landry, K. L. (2002). "Schemata in second language reading". The Reading Matrix,.2..3, available from: http://www.readingmatrix.com/articles/landry/index.html, accessed 16 May, 2010.

Levine, A. and Reves, T. (1998). " Data collecting on reading-writing strategies: A comparison of instruments: A case study". TESL-EJ.3,3, available from: http://tesl-ej.org/ej11/a1.html,, accessed 16 May, 2010.

Lotfiyan Moghadam, M. (2003). The Relationship between reflections through keeping language 
learning diaries, language learning strategies and language proficiency level of Iranian EFL learners. Unpublished master thesis, University of Tarbiat Moddares - Iran.

Macaro, E. (2003). Teaching and Learning a Second Language; A Guide to Recent Research and its Applications. Continuum. London - New York.

Nunan, D. (1988). Syllabus Design. Oxford: Oxford University Press. (Chapters 3 \& 4: 27-60).

Nunan, D. ( 2004). Task-based Language Teaching. Cambridge: Cambridge University Press.

O'Malley, J. M. \& Chamot, A. U. (1990). Learning Strategies in Second Language Acquisition. Cambridge University Press.

Oxford, R. L. (1985). A New Taxonomy of Second Language Learning Strategies. Washington, DC: Center for Applied Linguistics.

Oxford, R. L. (1990). Language Learning Strategies: What Every Teacher Should Know. Boston: Heinle \& Heinle publishers.

Oxford, R. L. (2001). " Language learning strategies", in M. Celce-

Murcia (ed), Teaching English as a Second or Foreign Language: (3rd ed). United States: Heinle \& Heinle, 359-366.

Oxford, R. , Cho, Y. , Leung, S. , \& Kim, H. J. (2004). "Effect of the presence and difficulty of task on strategy use: An exploratory study", in IRAL, 42, 1-47.

Oxford, R. L. \& Crookall, D. (1989). "Research on language learning strategies; Methods, findings, and instructional Issues", in The Modern Language Journal. 73, iv, 404-419.

Oxford, R. L. \& Ehrman, M. (1995). "Adult's language learning strategies in an intensive foreign language program in the United States", in System 23, 359-386.

Oxford, R. L. \& Nyikos, M. (1989). "Variables affecting choice of language learning strategies by university students", in The Modern Language Journal, 73, 3. 291-300.

Richards, J. C. (1990). Beyond Methods; the Language Teaching Matrix. Cambridge University Press.

Richards, J.C. \& Rodgers, T.S.(2001). Approaches and Methods in Language Teaching. Cambridge University Press.

Rubin, J. (1975). " What the good language learner can teach us", in TESOL Quarterly, 9, 1, 4151.

Rubin, J. (1987). " Learner strategies, theoretical assumptions, research history and typology", in A. Wenden, \& J. Rubin (1987) (eds.), Learner Strategies in Language Learning. Englewood Cliffs, NJ: Prentice Hall.

Stott, N. (2001). "Helping ESL students become better readers: Schema theory applications and limitations". The Internet TESL Journal, VII, 11, available from: http://iteslj.org/Articles/ Stott-Schema.html, accessed 16 May 2010.

Wenden, A. \& Rubin, J. (1987) Learner Strategies in Language Learning, Englewood Cliffs, NJ. Prentice Hall.

Willis, J. (1998). "Task-based learning: What kind of adventure? " Aston University, UK., available from: http://www.jalt-publications.org/tlt/files/98/jul/willis.html, accessed 16 May, 2010.

Yadegari, S. (2004). The relationship between personality type and foreign language learning strategies at a distance. Unpublished master thesis, University of Tarbiat Moddares - Iran. 